\title{
Good Governance and Anti-Corruption: Responsibility to Protect Universal Health Care in Indonesia
}

\author{
Ratna Juwita \\ Faculty of Law, Universitas Atma Jaya Yogyakarta, Indonesia. E-mail: ratna_juwita@mail.uajy.ac.id
}

\section{ARTICLE INFO}

Keywords:

Corruption; Good

Governance; Human Rights;

Universal Health Care

How to cite:

Juwita, R. (2018). Good

Governance and Anti-

Corruption: Responsibility

to Protect Universal Health

Care in Indonesia.

Hasanuddin Law Review,

4(2): 162-180

DOI:

10.20956/halrev.v4i2.1424

\begin{abstract}
The establishment of universal health care marks a new momentum for the progressive realization of the right to health in Indonesia. The problem of corruption in health sector endangers the sustainability of effective and quality health care, therefore, Indonesia established an anti-fraud system to protect the universal health insurance fund. This research seeks to analyze the current anti-fraud system in universal health insurance through the lens of international law and principles of good governance. The sociolegal approach is chosen to study the relationship between the State party obligations to international law and the implementation of international law concerning universal health care and anti-corruption in the designated anti-fraud system. Good governance principles are essential in designing an effective anti-fraud system due to the correlation between human rights and anti-corruption that both areas emphasize good governance principles as guiding principles for the realization of human rights and the making of potent anti-corruption strategy.
\end{abstract}

Copyright (C) 2018 HALREV. All rights reserved.

\section{Introduction}

Universal health insurance is pivotal to realize the right to health as means of universal health care financing. ${ }^{1}$ Universal health care (also known as universal health coverage or universal health care coverage) is measures to realize the right to health due to its main function to prevent financial hardship for patients, therefore, universal health care provides access to quality health care. ${ }^{2}$ The objective of universal health insurance

1 Indonesia uses the term "universal health insurance" instead of "universal health care" in the English translation, however, the meaning of the term is synonymous.

2 Tyler, E. T. (2013). “Small Places Close to Home: Toward A Health and Human Rights Strategy for the US". Health and Human Rights Journal, 15(2): 80-96. http://www.ncbi.nlm.nih.gov/pubmed/24421171; Farmer, P. \& Gastineau Nicole, G. (2002). "Rethinking Health and Human Rights: Time for A Paradigm Shift". Journal of Law and Medical Ethics, 30(4): 655-666; Türmen, T., Troedsson, H. \& Stahlhöfer, M. (2001). "A Human Rights Approach to Public Health: WHO Capacity Building in the Area of Children's Rights". Health and Human Rights Journal, 147-154; Yamin, A. E. (2010). "Our Place in the World: Conceptualizing Obligations Beyond Borders in Human Rights-Based Approaches to Health". Health 
as part of universal health care is to reduce out of pocket payments from the patients. Due to the significant amount of funds that are pooled, managed and distributed properly by the authoritative organ in universal health insurance, the funds are vulnerable to be corrupted. The problem of corruption in the health sector is severely hampering the effort of countries to properly establish effective universal health insurance for its citizen.

This phenomenon has to be responded with due diligence because corruption can destroy universal health insurance program from the inside and jeopardize the sustainability of the universal health care in general. Indonesia is chosen as the case study in this research due to the massive problem of corruption and early implementation of universal health insurance. Fraud is selected as the type of corruption due to its prevalent existence in health sector corruption. Fraud was also selected due to government's focus on fraud as part of combating corruption, especially in the health sector. ${ }^{3}$

Indonesia implemented universal health insurance program in 2014 with optimistic hope to cover the whole population by 2019.4 This is a progressive step taken by the Government to realize the right to health in Indonesia. As the member state of the International Covenant on Economic, Social and Cultural Rights (ICESCR), the Government of Indonesia is under the legal obligation to take measures progressively to respect, protect and fulfill the right to health. ${ }^{5}$ Article 12 of the ICESCR guaranteed the recognition that every human being has the right to the enjoyment of the highest attainable standard of physical and mental health. ${ }^{6}$ The State Party of the ICESCR is also obliged to take progressive steps with aims to achieve the realization of the right to health with focus to reduce child mortality, improvement of all aspects of environmental and industrial hygiene, prevention, treatment and control of disease and to create condition which would assure to all medical service and medical attention in the event of sickness in Article 12 (2). ${ }^{7}$

Based on the reports from the Ministry of Finance and the Social Insurance Administration Organization, there is a significant deficit in the universal health insurance and the deficit problem persists until now. ${ }^{8}$ Corruption is a persistent

and Human Rights Journal, 12(1): 3-14; Gro Harlem Brundtland, G. H. (1998). "Fifty Years of Synergy between Health and Rights". Health and Human Rights Journal, 3(2): 21-25.

3 The Ministry of Health, Indonesia, http://www.depkes.go.id/article/view/17022400006/kpk-gandengkemenkes-dan-bpjs-bentuk-satgas-pencegahan-dan-penanganan-fraud-sistem-jkn.html, accessed 13 January 2018; Jakarta Post, 23 February 2017, http://www.thejakartapost.com/news/2017/02/23/task-force-set-up-tocombat-jkn-fraud.html, accessed 13 January 2018; Jakarta Post, 24 February 2017, http://www. thejakartapost.com/news/2017/02/24/national-scene-task-force-set-combat-jkn-fraud.html, accessed 13 January 2018.

4 WHO, http://www.searo.who.int/indonesia/topics/hs-uhc/en/, accessed 8 December 2017.

5 CESCR General Comment No. 14: The Right to the Highest Attainable Standard of Health (Art. 12), $2000(2000)$.

6 Ibid.

7 International Covenant on Economic, Social and Cultural Rights, (1966) art. 12, 2, 993 U. N. T. S. 3.

8 Hidayat, B. et al. (2015). Financial Sustainability of the National Health Insurance in Indonesia: A First Year Review Indonesian-German Social Protection Programme (SPP), p. 1-8, https://goo.gl/dZGk3w accessed 10 December 2017; Jong, H. N. (2015) Poor cost control will worsen JKN deficit: Study, the Jakarta Post, http://www.thejakartapost.com/news/2015/07/22/poor-cost-control-will-worsen-jkn-deficit-study.html, accessed 13 January 2018; Faizal, E. B. (2017) How Can We Save Our National Health Insurance Program from Deficit?, the Jakarta Post, available online at: https://www.pressreader.com/indonesia/the-jakartapost/20170411/281547995752075, accessed 13 January 2018; Tempo, (2017) BPJS Faces Major Deficit in 2017, https://en.tempo.co/read/news/2017/02/10/055845185/BPIS-Faces-Major-Deficit-in-2017, accessed 13 January 2018. 
problem in Indonesia and it has a correlation with the deficit of the universal health insurance, albeit not the only problem. Concerning fraud in the health sector, the Ministry of Health and the Social Insurance Administration Organization have designated an anti-fraud system as an initial effort to combat fraud in the health sector. This research focuses on the current anti-fraud system designated by the Ministry of Health and the Social Insurance Administration Organization ${ }^{9}$ as means to combat fraud in health sector thus protecting the universal health insurance from corruption.

This sociolegal research seeks to explain, 1) Universal health insurance system in Indonesia and the State obligation to the right to health through the existence of universal health care, this part will explain the establishment of the anti-fraud system by historical approach, 2) Good governance in Indonesia and its implementation in universal health insurance, especially with regard to the ratification of the United Nations Convention Against Corruption (UNCAC), 3) The need to integrate good governance and anti-corruption strategy to protect universal health insurance in Indonesia by analyzing the current anti-fraud system through the synchronization with State party obligations under international law. Normative approach is taken to analyze the proposed idea of collaboration between good governance principle and anti-corruption strategy and identify the legal materials, official reports from the stakeholders, i.e, the Ministry of Health, Corruption Eradication Commission and NGOs and academic literature. The existence of an ideal anti-fraud system is crucial to guard the fund of universal health insurance, ipso facto, realize the right to health.

\section{Guarding Universal Health Insurance in Indonesia through the Establishment of an Anti-Fraud System}

Indonesia ratified the ICESCR through the Law number 11 of 2006.10 Due to the ratification, Indonesia has the international legal obligation to realize all of the rights contained in the ICESCR. Article 2(1) of the ICESCR obliges the State party to;

Each State Party to the present Covenant undertakes to take steps, individually and through international assistance and co-operation, especially economic and technical, to the maximum of its available resources, with a view to achieving progressively the full realisation of the rights recognised in the present Covenant by all appropriate means, including particularly the adoption of legislative measures.

One of the rights is the right to health as guaranteed in the article 12 of the ICESCR. Article 12 established the legal obligation of the State party to immediately take steps to realize the right to the highest attainable standard of health to all of its citizen.

Indonesia established Jaminan Kesehatan Nasional (JKN) as the universal health insurance program in 2014 through the Law number 40 of 2004 concerning the National Social Security System. ${ }^{11}$ The National Social Security system is conducted by the Social Insurance Administration Organization through the Law number 24 of $2001 .{ }^{12}$ It is a form of effort that is taken by the Government to respect, protect and fulfill the right to health of its constituents.

9 The Indonesian term for the Social Insurance Administration Organization is Badan Penyelenggara Jaminan Sosial Kesehatan or as abbreviated as BPJS Kesehatan.

10 United Nations Treaty Series, https://treaties.un.org/Pages/ViewDetails.aspx?src=INDEmtdsg_no=IV-

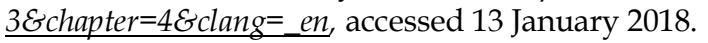

11 Indonesia, the Law Number 40 of 2004 concerning National Social Security System.

12 Indonesia, the Law Number 24 of 2001 concerning Social Insurance Administration Organization. 
Universal health coverage as defined by the World Health Organization (WHO) is,

Universal health coverage is defined as ensuring that all people have access to needed promotion, preventive, curative and rehabilitative health services, of sufficient quality to be effective, while also ensuring that people do not suffer financial hardship when paying for these services. ${ }^{13}$

Though it is a relatively new project, JKN has proven to be the suitable measures to realize the right to health due to its performing function as a bridge for the citizen to access quality health care.

Nafsiah Mboi as the former Minister of Health explained challenges and problems in the universal health insurance system, inter alia, corruption. ${ }^{14}$ Corruption remains an important problem in Indonesia. Indonesia ranked 90th based on the Corruption Perception Index (CPI) 2016 by Transparency International. ${ }^{15}$ This is the evidence that Indonesia is still struggling with the elimination of corruption. Research has proven that corruption in Indonesia is rampant and pervasive as the cases and documents have shown that corruption happened in massive scale and in any sector of governance. ${ }^{16}$ In the past, Indonesia was controlled by an authoritarian government with strong military power, it had resulted in weak rule of law and democracy. ${ }^{17}$ During the New Order era, corruption flourished as result of the authoritarian model of government. ${ }^{18}$ After the political turmoil that leads to the downfall of Soeharto in 1998, Indonesia is on the new era of fighting corruption, however, the recess of systemic failure to prevent and combat corruption in New Order makes the law reform and anti-corruption agenda become very challenging.

JKN is a vulnerable program to be corrupted, this hypothesis is derived from the facts that there are many legal cases of corruption in JKN program, inter alia, embezzlement and fraud of JKN fund.19 Based on the Annual Report of the Social Insurance Administration Organization, in 2016, JKN covers 171.939.254 persons. The total amount of fund per 31 December 2016 is 10.344.737.000.000,00 rupiah. ${ }^{20}$ Without a thorough supervision of the fund, the risk of corruption is too high. Though Indonesia has a legal continuum concerning anti-corruption, the empirical legal studies shown that

$13 \mathrm{WHO}$, http://www.who.int/mediacentre/factsheets/fs395/en/, accessed 9 January 2018.

14 Mboi, N. (2015) "Indonesia: On The Way to Universal Health Care", Health System Reform, 1(2):91-97, http://www.tandfonline.com/doi/full/10.1080/23288604.2015.1020642.

15 Transparency International, Corruption Perception Index: Indonesia, 2016. Source: https://www.ti.or.id/index.php/publication/2017/01/25/corruption-perceptions-index-2016, $\quad$ accessed 13 January 2018.

16 Butt, S. (2011). “Anti-corruption Reform in Indonesia: An Obituary?”, Bulletin of Indonesian Economic Studies 47(3): 381-394.; Butt, S. (2009). "Unlawfulness and Corruption Under Indonesian Law”, Bulletin of Indonesian Economic Studies, 45(2): 179-198; Setiyono, B. \& McLeod, R. H. (2010). "'Civil Society Organisations' Contribution to the Anti-corruption Movement in Indonesia", Bulletin of Indonesian Economic Studies, 46(3): 347-370.

17 McLeod, R. H. (2000). “Soeharto's Indonesia: A Better Class of Coruption”, Agenda: A Journal of Policy Analysis and Reform, 7(2): 99-112.

18 Ibid.

19 Juwita, R. (2017). "Health Sector Corruption as the Archenemy of Universal Health Care in Indonesia", Mimbar Hukum, 29(1):162-175.

20 BPJS Kesehatan, (2015). Laporan Pengelolaan Program Tahun 2016 and Laporan Keuangan Pengelolaan Program Tahun 2016 (Audit), Jakarta: BPJS Kesehatan, http://bpjskesehatan.go.id/bpjs/index.php/arsip/detail/835. 
corruption is still a problem in the reality. ${ }^{21}$ During the visitation from the United Nations Special Rapporteur on the right to health, Dainius Puras addressed that Indonesia is struggling to implement the health plan and facing financial difficulties. ${ }^{22}$ Corruption in the health sector directly undermines the Government's efforts to protect the health of every individual in society. ${ }^{23}$ In Indonesia, as a developing country, scarce and under quality health providers are already a problem, corruption exacerbates the situation. Universal health insurance aims to help people and especially the poor to access quality health care through universal coverage but corruption in health financing diverts the fund away from people who need it the most. ${ }^{24}$

The ratification of the ICESCR in 1996 created the consequence of the establishment of human rights obligations to respect, protect and fulfil economic, social and cultural rights. The right to health is also protected under the Universal Declaration of Human Rights (UDHR) in the Article 25 (1). ${ }^{25}$ Progressively, the right to health is integral in Article 5 (e) (iv) of the International Convention on the Elimination of All Forms of Racial Discrimination, Article 11 (1) (f) and 12 of the Convention on the Elimination of All Forms of Discrimination Against Women, Article 9, 25 and 26 of the Convention on the Rights of Persons with Disabilities and Article 24 of the Convention on the Rights of the Child. ${ }^{26}$ Regional human rights instruments also integrates the existence of right to health in their articles, such as, article 11 of the European Social Charter, article 16 of the African Convention on Human and People's Rights, article 14 of the African Charter on the Rights and Welfare of the Child, article 10 of the Additional Protocol to the American Convention on Human Rights in the Area of Economic, Social and Cultural Rights. ${ }^{27}$

The Committee on Economic, Social and Cultural Rights (Comm ESCR) explained in the General Comment number 14 that the right to the highest attainable standard of health must be understood as the right to the enjoyment of a variety of facilities, goods, services and conditions necessary for the realization of the highest attainable standard of health. ${ }^{28}$ In 2014, Indonesia reformed and renamed its previous health insurance program into JKN. Before JKN, Indonesia has several health insurance programs with various stakeholders addressed, inter alia, Jaminan Kesehatan Masyarakat (Jamkesmas)

21 Hamilton-Hart, N. (2001). "Anti-corruption Strategies in Indonesia”, Bulletin of Indonesian Economic Studies, 37(1):65-82; Sherlock, S. (2002). “Combating Corruption in Indonesia? The Ombudsman and the Assets Auditing Commission", Bulletin of Indonesian Economic Studies, 38(3): 367-383.

22 OHCHR, http://www.ohchr.org/EN/NewsEvents/Pages/DisplayNews.aspx?NewsID=21476ELangID=E, accessed 11 January 2018.

23 UNODC, Thematic Programme- Action Against Corruption, Economic Fraud \& Identity-Related Crime (20122015), (2012), p. 6, http://www.unodc.org/documents/corruption/Thematic_Programme/Thematic_Programme_ on_Corruption_-2012-2015_sept12.pdf.

24 Ibid.

25 Universal Declaration of Human Rights, art. 25, 1948, U. N. G. A. RES 217 (III), U. N. DOC A/810, 71.

26 International Convention on All Forms of Racial Discrimination, 1966, 660 U. N. T. S. 195; Convention on the Elimination of All Forms of Discrimination Against Women, Dec. 18, 1979, 1249 U. N. T. S. 13; Convention on the Rights of Persons with Disabilities, 2007, A/RES/61/106; Convention on the Rights of the Child, Nov. 1989, 1577 U. N. T. S. 3.

27 European Social Charter, art. 11 and 13, Feb. 26, 1965, 529 U. N. T. S. 89; African Convention on Human and People's Rights, art. 16, 1982, 21 I. L. M. 58; African Charter on the Rights and Welfare of the Child, art. 14, 1990, O. A. U. Doc. CAB/LEG/24.9/49; Additional Protocol to the American Convention on Human Rights in the Area of Economic, Social and Cultural Rights (Protocol San Salvador), 1988, O. A. S. T.S. 69.

28 CESCR General Comment No. 14: The Right to the Highest Attainable Standard of Health (Art. 12), supra note. 
that was intended to cover health care expenses for the poor. ${ }^{29}$ Though JKN is a relatively new program, the Government aims an ambitious goal that is to universally cover all of its citizen by 2019.30

Based on the Regulation of Social Insurance Administration Organization number 1 of 2014 concerning the governance of health insurance, health insurance is defined as insurance in the form of health care protection designated so the insured obtains the benefit of basic health care and protection of it. Health care service is given to the insured whom the status is dichotomized between a person who pays for himself or herself and the person whom the premium is paid by the Government. Indonesia implements the Tarif Indonesian-Case Based Groups as the parameter of the claim that is paid by the Social Insurance Administration Organization to the Health Facilities for the service package based on the categorization of disease diagnosis. ${ }^{31}$

\section{UNCAC and Good Governance: Implementation in Indonesia}

The universal fight against corruption has been started through the establishment of the UNCAC in 2003.32 Prior to the establishment of UNCAC, several legally binding international legal instruments have been created by the states, inter alia, Organization for Economic Cooperation and Development Convention on Combating Bribery of Foreign Public Officials in International Business Transactions, the Convention on the Fight against Corruption involving Officials of the European Communities or Officials of Member States of the European Union, the Criminal Law Convention on Corruption, the Civil Law Convention on Corruption, the Inter-American Convention Against Corruption, and the African Union Convention on Preventing and Combating Corruption. ${ }^{33}$ Ratification of United Nations Convention Against Corruption (UNCAC) in 2006 by the Indonesian government created a legal obligation to take measures in executive, legislative and administrative field to combat corruption. ${ }^{34}$

The UNCAC emphasizes explicitly the principles of good governance in most of the provisions, for instance, in Article 7 (1) (a) concerning Public Sector, UNCAC mandates that the State Party has to adopt, maintain and strengthen systems for the recruitment,

29 Hidayat et al, supra note.

30 Ibid; WHO, Universal Health Coverage and Health Financing in Indonesia, http://www.searo. who.int/indonesia/topics/hs-uhc/en/, accessed 13 January 2018; Faizal, E. B. (2014). 8.5 million employees registered as BPJS members as of January: Ministry, the Jakarta Post, http://www.thejakartapost.com/news/2014/02/04/85-million-employees-registered-bpjs-members-januaryministry.html, accessed 13 January 2018; Razavi, L. Indonesia's universal health scheme: one year on, what's the verdict?, the Guardian, https://www.theguardian.com/global-development-professionalsnetwork/2015/may/15/indonesias-universal-healthcare-insurance-verdict, accessed 13 January 2018.

31 Indonesia, Presidential Decree number 12 of 2013 concerning the Health Insurance Program, 1-46 (2016).

32 United Nations Convention Against Corruption, Oct. 31, 2003, 2349 U. N. T. S. 41.

33 Id. P. 7; Organization for Economic Cooperation and Development, Convention on Combating Bribery of Foreign Public Officials in International Business Transactions, Dec. 17, 1997, S. Treaty Doc. No. 10543; European Union, Convention on the Fights against Corruption involving Officials of the European Communities or Officials of Member States of the European Union, May. 26, 1997, Off. J. C195/1; Council of Europe, Criminal Law Convention, Jan. 27, 1999, 2216 U. N. T. S. 225; Council of Europe, Additional Protocol to the Criminal Law Convention on Corruption, May. 15, 2003, 2466 U. N. T. S. 168; Council of Europe, Civil Law Convention on Corruption, Nov. 4, 1999, 2246 U. N. T. S. 4; Organization of American States, Inter-American Convention Against Corruption, Mar. 29, 1996, S. Treaty Doc. No. 105-39, 35 I.L.M 724; African Union, African Union Convention on Preventing and Combating Corruption, Jul. 11, 2003, 43 I. L. M. 5.

34 United Nations Treaty Series, https://www.unodc.org/documents/treaties/UNCAC/COSP/session4/ V1186007e.pdf, accessed 12 December 2017. 
hiring, retention, promotion and retirement of civil servants and, where appropriate, other non-public officials that based on principles of efficiency, transparency and objective criteria such as merit, equity and aptitude. ${ }^{35}$ In Article 9 with reference to Public Procurement and Management of Public Finances, the UNCAC obliges the State Party to promote transparency and accountability in the management of public finances. ${ }^{36}$ As regards to the participation of society, the UNCAC in Article 13 regulates that participation of society should be strengthened by measures such as enhancing the transparency of and promoting the contribution of the public to the decision-making process. ${ }^{37}$

UN has formulated several good governance and its relation to human rights instruments, started from the UN Commission on Human Rights resolution 2000/64 The role of good governance in the promotion of human rights in 27 April 2000, the UN Commission on Human Rights, Commission on Human Rights Resolution 2003/65: The Role of Good Governance in the Promotion of Human Rights in 24 April 2003, the UN Commission on Human Rights, Commission on Human Rights Resolution 2004/70: The Role of Good Governance in the Promotion of Human Rights in 21 April 2004 and the UN Commission on Human Rights, Human Rights Resolution 2005/68: The Role of Good Governance in the Promotion and Protection of Human Rights in 20 April 2005. Those are foundation for good governance and its relationship to human rights.

The UN emphasizes the points of good governance are transparency, responsibility, accountability, participation and responsiveness to the needs of the people. ${ }^{38}$ However, on theoretical realms, there are various definitions of good governance. Several definitions are explained to describe good governance concept. The Office of the High Commissioner on Human Rights (OHCHR) defined good governance as the exercise of authority through political and institutional processes that are transparent and accountable, and encourage public participation. ${ }^{39}$ There are four areas where human rights and good governance are related, democratic institutions, the delivery of State services, the rule of law and anti-corruption measures. The OHCHR publication explained that human rights and good governance are mutually reinforcing. ${ }^{40}$

Good governance is the theory that believes in transparency and accountability as means to establish a good government. ${ }^{41}$ Indonesia has regulated the implementation of good governance in the Law number 28 of 1999 concerning Clean Governance Free from Corruption, Collusion and Nepotism. ${ }^{22}$ The Law number 28 of 1999 is in conjunction with the anti-corruption laws is deemed as completion of the legal continuum on anti-corruption in Indonesia, also as integrated measures to implement the UNCAC State's obligations. Nevertheless, the challenge concerning the enforcement of those principles into every sect of governance remains. The Article 3 of the Law number 28 of 1999 mandates that governance principles assure legal certainty,

35 Id.

36 Id.

37 Office of the High Commissioner for Human Rights, (2007). Good Governance Practices for the Protection of Human Rights, Geneva: United Nations, p. 59-77.

38 Commission on Human Rights. (2004). Resolution 2000/64, The Role of the Good Governance in the Promotion of Human Rights, p. 1-4.

39 Office of the High Commissioner for Human Rights, supra note 39.

40 Ibid.

41 United Nations, supra note.

42 Indonesia, the Law No. 28 of 1999 concerning Clean Governance Free from Corruption, Collusion and Nepotism. 
discipline in governance, governance aims for the public interest, transparency, proportionality, professionalism and accountability. The UNCAC in Article 8 regulates that the State Party has to promote good governance values among its public officials in accordance with the fundamental principles of its legal system and also apply codes or standards of conduct concerning the correct, honorable and proper performance of public functions, within its own institutional and legal systems. ${ }^{43}$ The Law number 28 of 1999 is the core legal basis in Indonesia concerning good governance, however, the rules that are crystalized in the law is general in nature and has to be regulated further to ensure its enforcement and cooperativeness.

\section{Good Governance and Anti-Corruption: Responsibility to Protect Universal Health Care in Indonesia}

Corruption, once it is institutionalized and penetrates the culture of society, it will become very hard to be eradicated and Indonesia is in that particular situation. Indonesia has a long history of corruption, in the New Order era, there are myriad grand corruption cases which the perpetrators are high ranking officials. ${ }^{44}$ For the specific study, the health sector is prone to be corrupted due to the long chain of bureaucracy, complicated legal rules, complex system and massive amount of fund are forming the structure of corruption risk in Indonesia. From the positivist perspective, universal health insurance system in Indonesia has been protected by the designated legal continuum on anti-corruption and supplemented by the internal anti-corruption system within the Social Insurance Administration Organization as the institution with authority to manage JKN fund.

There are three legal instruments established to create the anti-fraud system in the Indonesian universal health insurance, those are: The Presidential Decree Number 19 of 2016 concerning the Second Change of Presidential Regulation with regard to Health Insurance (Peraturan Presiden Republik Indonesia Nomor 19 Tahun 2016 tentang Perubahan Kedua Atas Peraturan Presiden Nomor 12 Tahun 2012 tentang Jaminan Kesehatan); The Ministry of Health Regulation Number 36 of 2015 concerning the Prevention of Fraud in the Implementation of Health Insurance Program within the National Social Security System (Peraturan Menteri Kesehatan Republik Indonesia Nomor 36 Tahun 2015 tentang Pencegahan Kecurangan dalam Pelaksanaan Program Jaminan Kesehatan pada Sistem Jaminan Sosial Nasional); and The Social Insurance Administration Organization Rules Number 7 of 2016 concerning the System of Fraud Prevention in the Implementation of Health Insurance Program (Peraturan Badan Penyelenggara Jaminan Sosial Kesehatan Nomor 7 Tahun 2016 tentang Sistem Pencegahan Kecurangan (Fraud) dalam Pelaksanaan Program Jaminan Kesehatan).

43 Hamilton-Hart, supra note; Butt, supra note; Suryadarma, D. (2012). "How Corruption Diminishes the Effectiveness of Public Spending on Education in Indonesia”, Bulletin of Indonesian Economic Studies, 48(1): 85-100.

44 Gathii, J. T. (2009). "Defining the Relationship between Human Rights and Corruption", University of Pennsylvania Journal of International Law, 31(1):125-202; OECD. (2008). Corruption: A Glossary of International Standards in Criminal Law, Paris: OECD, p. 21-39; Transparency International. (2014). Protecting Climate Finance-An Anti Corruption Assessment of the UN-REDD Programme, Berlin: Transparency International, p. 38-54; Office of the United Nations High Commissioner for Human Rights. (2013). The Human Rights Case Against Corruption, United Nations, p. 1-20, http://www.ohchr.org/Documents/Issues/Development/GoodGovernance/Corruption/HRCaseAgainstCorruption .pdf accessed 10 December 2017. 
In Article 1 (14. a) of the Presidential Decree, fraud in health insurance is defined as an intentional act to obtain financial benefit from the National Health Insurance Program in the National Social Security System through fraudulent means that is not in accordance with the rules. 45 The Presidential Decree further regulates the provisions concerning fraud in the Chapter XIA. In Article 46A (1), the provision mandated the stakeholders in universal health care; the Social Insurance Administration Organization, city and district public health offices and health facility providers which have cooperation with Social Insurance Administration Organization to establish an anti-fraud system within the Health Insurance Program. ${ }^{46}$ The subsequent article emphasized that the perpetrators of fraud can vary from the insured and the insurers. ${ }^{47}$

In the Article $46 \mathrm{~A}$ (3), the anti-fraud system shall be established through the formulation of policy and guidelines to prevent fraud, the development of fraud prevention culture, the development of health service that focuses on quality and tariff control and the last is the establishment of an anti-fraud task force. ${ }^{48}$ The anti-fraud system shall be conducted through systemic, structured and comprehensive means and it has to involve all human resources in the Social Insurance Administration Organization, health facility providers public health offices in all levels of governance and the rest of the stakeholders. ${ }^{49}$ The Presidential Decree regulates general issues on the establishment of an anti-fraud system and the Regulation mandates further legal formulation of the system in the level of Ministerial legal instruments. 50

The Ministry of Health Regulation Number 36 of 2015 concerning Fraud Prevention in the Implementation of Health Care Program within the National Social Security System establishes more concrete rules of the anti-fraud system. In Article 1, the Ministry of Health expands the definition of fraud from the Presidential Decree. Fraud is defined as an intentional act conducted by the member of JKN, the Social Insurance Administration Organization employee, health service provider and medicine and medical devices providers to gain financial benefit from Health Insurance program within National Social Security system through fraudulent activities that are not in accordance with the rules. 51

Article 2 reiterates the spirit of Article 46 A (2) of the Presidential Decree that emphasizes the possible actors to commit fraud are the insured and the insurers (the employee of Social Insurance Administration Organization, health care provider and medicine provider). ${ }^{52}$ The typology of fraudulent activities as regulated in the Ministry of Health Regulation Number 36 of 2015 concerning Fraud Prevention in the Implementation of Health Insurance Program within the National Social Security System as shown in the Table 1.

The typology of fraud in the Ministry of Health Regulation is comprehensive and operative due to its specific definition of fraudulent activities that hypothetically might be conducted by the respective actors within the universal health insurance system, those are the member of JKN, the employee of Social Insurance Administration Organization, health facilities, medical devices and medicine providers. Concerning

45 Article 1 (14. a) of the Presidential Decree.

46 Article 46 A (91) Presidential Decree.

47 Article 46 A (2) Presidential Decree.

48 Article 46 A (3) Presidential Decree.

49 Article 46 A (4) Presidential Decree.

50 Article 46 A (5) Presidential Decree.

51 Article 1 of the Ministry of Health Regulation.

52 Article 2 of the Ministry of Health Regulation. 
the fraud prevention mechanism, the Ministry of Health established three prongs approach based on stakeholders' tasks to prevent fraud in health insurance (Table 2).

Table 1. Typology of fraudulent activities as regulated in The Ministry of Health Regulation Number 36 of 2015

\begin{tabular}{|c|c|c|c|}
\hline No & Provisions & Stakeholders & Typology of fraudulent activities \\
\hline 1. & Article 3 & Member of JKN & $\begin{array}{l}\text { a. to make a deceptive statement concerning eligibility (falsification of } \\
\text { membership status) to gain medical service. } \\
\text { b. to harness the right to obtain unnecessary services through the } \\
\text { means of falsifying medical condition. } \\
\text { c. to give gratification to the service provider in order to make the } \\
\text { provider gives medical service that is not in accordance with the } \\
\text { rules and also uncovered medical service. } \\
\text { d. to manipulate JKN member's income so that there is no need to pay } \\
\text { for higher premium. } \\
\text { e. to make cooperation with health service provider to submit a fake } \\
\text { claim. } \\
\text { f. to obtain medicine and/or medical devices that are prescribed with } \\
\text { g. to conduct other fraudulent activities other than letter a to letter } \mathrm{f} \text {. }\end{array}$ \\
\hline 2. & Article 4 & $\begin{array}{l}\text { The employee of } \\
\text { Social Insurance } \\
\text { Administration } \\
\text { Organization }\end{array}$ & $\begin{array}{l}\text { a. to cooperate with member and/or health service provider to submit } \\
\text { a fake claim; } \\
\text { b. to manipulate benefit that is not supposed to be covered in order to } \\
\text { be covered; } \\
\text { c. to hold payment to health facility/partner with the objective to } \\
\text { obtain private gain; } \\
\text { d. to pay capitation fund that is not in accordance with the rules; } \\
\text { e. to conduct other fraudulent activities in JKN apart from the letter a } \\
\text { to the letter } \mathrm{d} \text {. }\end{array}$ \\
\hline 3. & $\begin{array}{l}\text { Article } 5(2) ; \\
\text { and } \\
\text { Article } 6 .\end{array}$ & $\begin{array}{l}\text { Health service } \\
\text { provider } \\
\text { (divided into the } \\
\text { first level health } \\
\text { facility and } \\
\text { advanced } \\
\text { referral health } \\
\text { facility). }\end{array}$ & $\begin{array}{l}\text { a. to harness the capitation fund that is not in accordance with } \\
\text { begulation; } \\
\text { b. to manipulate Claim in the service that is paid by non-capitation } \\
\text { c. to accept commission based on references to advanced referral } \\
\text { health facilities; } \\
\text { d. to extract payment from the member whom should have been } \\
\text { covered by capitation fund and/or non-capitation in accordance } \\
\text { with determined standard tariff; } \\
\text { e. to conduct patient references that is not in accordance with the } \\
\text { objective to gain particular benefit; and/or } \\
\text { f. other fraudulent activities apart from the letter a to the letter e. } \\
\text { a. upcoding; } \\
\text { b. cloning; } \\
\text { c. phantom billing; } \\
\text { d. inflated bills; } \\
\text { e. services unbundling or fragmentation; } \\
\text { f. self-referrals; } \\
\text { g. repeat billing; } \\
\text { h. prolonged length of stay; } \\
\text { i. to manipulate the type of room charge; } \\
\text { j. to make canceled services; } \\
\text { k. to conduct activities that have no medical value; } \\
\text { l. deviance from the standard of care; } \\
\text { g. m, to conduct unnecessary treatment; } \\
\text { m. to prolong the use of ventilator; } \\
\text { n. to conduct phantom visit; } \\
\text { o. to make phantom procedures; } \\
\text { p. readmission; } \\
\text { q. to make reference that is not in accordance with the objective to gain } \\
\text { r. to ask for cost sharing that is not in accordance with the regulation; } \\
\text { letter (s). }\end{array}$ \\
\hline
\end{tabular}




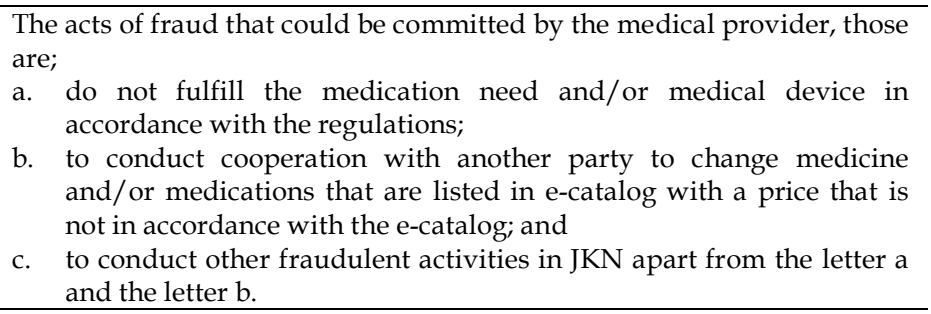

Table 2. Three prongs approach to fraud prevention in JKN.

\begin{tabular}{|c|c|c|c|}
\hline No & Provisions & Stakeholders & Measures to Prevent Fraud \\
\hline 1. & Article 8 & $\begin{array}{l}\text { Social Insurance } \\
\text { Administration } \\
\text { Organization }\end{array}$ & $\begin{array}{l}\text { a. the establishment of JKN fraud prevention policy and guidelines in the } \\
\text { Social Insurance Administration Organization; } \\
\text { b. the development of JKN fraud prevention culture as part of good } \\
\text { organization management; and } \\
\text { c. the establishment of JKN fraud prevention team in the Social } \\
\text { Insurance Administration Organization. }\end{array}$ \\
\hline 2. & Article 9 & $\begin{array}{l}\text { City and District } \\
\text { Public Health } \\
\text { Offices }\end{array}$ & $\begin{array}{l}\text { a. the making of JKN fraud prevention policy and guidelines; } \\
\text { b. the development of health service that oriented in quality and cost } \\
\text { control; and } \\
\text { c. the development of JKN fraud prevention culture as part of the good } \\
\text { organization and clinical management. }\end{array}$ \\
\hline 3. & $\begin{array}{l}\text { Article } \\
\text { (4) }\end{array}$ & $\begin{array}{l}\text { City and District } \\
\text { Public Health } \\
\text { Offices }\end{array}$ & $\begin{array}{l}\text { a. the socialization of policy, guidelines and a new culture that oriented } \\
\text { in quality and cost control; } \\
\text { b. to foster the implementation of good organization and clinical } \\
\text { management; } \\
\text { c. to conduct prevention, detection and enforcement measures against } \\
\text { d. to solve JKN fraud dispute; } \\
\text { e. monitoring and evaluation; and } \\
\text { f. reporting. }\end{array}$ \\
\hline
\end{tabular}

The principles of good governance are reiterated in Article 16 concerning underlying principles of the anti-fraud system. The principles are transparency, accountability, responsibility, independence and reasonableness. ${ }^{53}$

Chapter V of the Ministry of Health Regulation dictated the administrative sanction for the perpetrator of fraud in health insurance. Article 28 (2) mandated that the administrative sanctions are a verbal warning, written reprimand and/or order to return the loss of the fund due to the committed fraud. ${ }^{54}$ The Regulation also doubles the punishment in case the perpetrators are providers of health service and medicine in Article 28 (3). A further violation can also lead to the possibility of the revocation of medical practice license. ${ }^{55}$ In case the perpetrator of fraud is BPJS officials, the range of administrative punishment is wider, that includes verbal warning, written reprimand, suspension, dismissal or the order to return the loss of fund due to the fraud. ${ }^{6}$ The sanctions are dominated by administrative sanctions. However, most of the measures are broadly defined and not operative in legal wordings.

The Social Insurance Administration Organization also established the rules concerning anti-fraud system in the Regulation of Social Insurance Administration Organization number 7 of 2016 concerning Fraud Prevention System in the Implementation of Health Insurance Program. The regulation established a team with

53 Article 16 of the Ministry of Health Regulation.

${ }^{54}$ Article 28 (2) of the Ministry of Health Regulation.

55 Article 28 (3) of the Ministry of Health Regulation.

56 Article 29 (1) and (2) of the Ministry of Health Regulation. 
the task to prevent fraud in national health insurance in Article 1. The establishment of the task force is further explained in Article 3. The task force is the direct realization of efforts to prevent fraud in JKN. The regulation reiterates various classification of fraudulent activities in Chapter $\mathrm{V}$, the classifications that have been regulated by the Ministry of Health Regulations. The Social Insurance Administration Organization Regulations uses three prongs solution to prevention of fraud, those are preventive action, detection and enforcement. 57 Prevention of fraud is further explained in reporting the analysis concerning health service data, auditing reports and whistleblower. 58 The rules managed to set three categories of actions for fraud prevention for several related stakeholders (Table 3).

Table 3. Anti-Fraud System by the Social Insurance Administration Organization Regulation.

\begin{tabular}{|c|c|c|c|}
\hline $\begin{array}{c}\text { Stakeholders/ } \\
\text { Measures }\end{array}$ & Prevention & Detection & Enforcement \\
\hline $\begin{array}{l}\text { Member of JKN } \\
\text { (Article 12-14) }\end{array}$ & $\begin{array}{l}\text { Prevention action focuses } \\
\text { on education concerning } \\
\text { fraud prevention towards } \\
\text { the member of JKN through } \\
\text { the making of anti-bribery } \\
\text { commitment and periodical } \\
\text { screening of JKN identity } \\
\text { numbers. }\end{array}$ & $\begin{array}{l}\text { Detection action focuses on JKN } \\
\text { identity numbers screening, the } \\
\text { originality and legality of } \\
\text { referral letter, ensuring the } \\
\text { compliance of hospital with the } \\
\text { standard operational procedure, } \\
\text { providing application to detect } \\
\text { patient whom obtained benefit } \\
\text { that is not in accordance with the } \\
\text { rules, examining the compliance } \\
\text { of health facility and medical } \\
\text { providers with the rules, obliged } \\
\text { the health facilities to provide } \\
\text { notes of referrals and provide } \\
\text { information of fraud detection to } \\
\text { the Social Insurance } \\
\text { Administration Organization. }\end{array}$ & $\begin{array}{l}\text { Enforcement action varies from } \\
\text { suspension of insurance, reporting the } \\
\text { case to the public health office, health } \\
\text { facility association and hospital } \\
\text { committee with regard to the bribery } \\
\text { accepted by health service provider, } \\
\text { sanction in accordance with the } \\
\text { regulations concerning the member of } \\
\text { JKN whom manipulated the income } \\
\text { and reporting the member of JKN to } \\
\text { the law enforcement agency if there is } \\
\text { sufficient evidence of fraudulent } \\
\text { activity conducted by the member. }\end{array}$ \\
\hline $\begin{array}{l}\text { Employee of } \\
\text { Social Insurance } \\
\text { Administration } \\
\text { Organization } \\
\text { (Article 15-17) }\end{array}$ & $\begin{array}{l}\text { Prevention measures focus } \\
\text { on developing the culture of } \\
\text { good organization and } \\
\text { management, education and } \\
\text { monitoring of the } \\
\text { employees. There is also } \\
\text { obligations to improve } \\
\text { coordination between } \\
\text { employees to strengthen the } \\
\text { anti-fraud system and the } \\
\text { use of standardization of } \\
\text { business. }\end{array}$ & $\begin{array}{l}\text { Detection measures are in forms } \\
\text { of periodical audit and evalu- } \\
\text { ation by the anti-fraud task force } \\
\text { and also internal monitoring } \\
\text { body. }\end{array}$ & $\begin{array}{l}\text { Enforcement measures are divided into } \\
\text { enforcement on the district level and } \\
\text { national level. In case of fraud detection } \\
\text { with sufficient evidence, the head of the } \\
\text { respective office will report the } \\
\text { detection fraud case to the higher } \\
\text { authority of the Social Insurance } \\
\text { Administration Organization. The anti- } \\
\text { fraud task force will also investigate the } \\
\text { case. The final report will be sent to the } \\
\text { Head of the Human Resources } \\
\text { Department. }\end{array}$ \\
\hline $\begin{array}{ll}\text { Health } & \text { Service } \\
\text { Provider } & \text { (Article } \\
\text { 18- 21) } & \end{array}$ & $\begin{array}{l}\text { Prevention measures are the } \\
\text { making of fraud prevention } \\
\text { provision in the contract } \\
\text { between provider and } \\
\text { agency also with integrity } \\
\text { pact, education, monitoring } \\
\text { and evaluation concerning } \\
\text { fraud prevention. }\end{array}$ & $\begin{array}{l}\text { Detection measures are } \\
\text { conducted based on data claim } \\
\text { of health providers, } \\
\text { investigating of whistleblower } \\
\text { report and to provide } \\
\text { investigation data to the head of } \\
\text { first level health facilities and } \\
\text { advanced referral health } \\
\text { facilities. }\end{array}$ & $\begin{array}{l}\text { Enforcement measures conducted } \\
\text { mainly by the anti-fraud task force. The } \\
\text { anti-fraud task force from the branch } \\
\text { office will investigate the detection of } \\
\text { fraud in its respective jurisdiction. } \\
\text { There is a possibility to include the } \\
\text { team of quality and price control of the } \\
\text { district public health offices to conduct } \\
\text { co-investigation. } \\
\text { The reports of investigation must } \\
\text { consist of the decision whether fraud } \\
\text { has happened, the recommendation to } \\
\text { prevent fraud and sanction for the } \\
\text { perpetrator. The report will be given to } \\
\text { the head of the public health offices and } \\
\text { social security agency Social Insurance } \\
\text { Administration Organization. } \\
\text { In the case of fraud, the Social Insu- } \\
\text { rance Administration Organization will } \\
\text { not pay the amount of fund that is } \\
\text { determined as fraud and further, the } \\
\text { case can be taken to the law enfor- } \\
\text { cement agency. }\end{array}$ \\
\hline
\end{tabular}

57 Article 6 of the Social Insurance Administration Organization Regulation.

58 Article 7 of the Social Insurance Administration Organization Regulation. 
Sanctions are regulated in Chapter V (Article 22-26), the range of sanctions are myriad from the suspension of payment to the reporting the case to the law enforcement agencies so the case will be processed through the criminal justice process. ${ }^{59}$ The general definition of corruption is the abuse of power for private gain. ${ }^{60}$ Fraud, as defined as an activity, can vary from embezzlement to money laundering, even though every country has their own legal definition of fraud. ${ }^{61}$ In the press conference, the Social Insurance Administration Organization explained that in 2015, there were 175.000 claims suspected to be fraudulent and up to 1 million potentially fraudulent claims detected. ${ }^{62}$ As a comparison of the problem, $\mathrm{Lu}$ and Hsiao explained that in Taiwan National Health Insurance program, fraudulent activities cause a more financial burden for the Government to cover the citizen, therefore the Government works to reduce overcharges, duplications and overused health services. 63

Socio-legal studies seek to correct the problem between the law in the book and the law in action. ${ }^{64}$ The problem with the Indonesian health insurance is the discrepancies between the efforts to establish an ideal universal health care with zero corruption in a country that is still struggling to combat corruption, especially in the health sector. The international legal obligations emerged in this situation is the obligations stemmed from the international human rights instruments and anti-corruption instruments. The human rights obligation is derived from the ratification of international human rights instruments and the anti-corruption obligation is derived from the UNCAC. Both obligations are necessary to connect the law in the book and the law in action to make an effective anti-fraud system to realize ideal universal health care in Indonesia.

The UNCAC emphasized rule of law, transparency and integrity throughout the whole Convention. The essence of good governance is embodied almost in every provision of the UNCAC. The UNCAC obliges the State Party to establish a code of conduct for public officials. The code of conduct main elements is transparency and accountability. The code of conduct has been adopted preexistent by Indonesia before the ratification of the UNCAC, however, the rules are very broad and general. The rules mainly regulate the principles of good governance and it has no operationalized clauses. The challenge then is to operationalize the good governance principles as it has been crystallized in the Law number 28 of 1999 concerning Clean Governance Free from Corruption, Collusion and Nepotism.

The ratification of UNCAC obliges the State party to take executive, legislative and administrative measures to combat corruption. Indonesia has promulgated the legal continuum concerning corruption eradication, those are the Law number 31 of 1999 and the Law number 20 of 2001 concerning corruption eradication. Based on the Article 6 of the UNCAC, the State party has the obligation to ensure the existence of a

59 Article 22-26 the Social Insurance Administration Organization regulation.

60 Office of the United Nations High Commissioner for Human Rights. (2013). The Human Rights Case Against Corruption, p. 1-20.

61 Lu, R. J. \& Hsiao, W. C. (2003). “Does Universal Health Insurance Make Health Care Unaffordable? Lessons from Taiwan", Health Affairs, 22(3):77-88.

62 The Social Insurance Administration Organization, https://bpjs-kesehatan.go.id/bpjs/index.php/post/read/ 2017/534/Bersama-Wujudkan-Program-IKN-KIS-Bebas-dari-Kecurangan, accessed 12 December 2017.

63 Salter, M. \& Mason, J. (2007). Writing Law Dissertations Conduct of Legal Research, Edinburgh: Pearson Education Limited, p. 119.

64 United Nations, supra note. p. 130. 
preventive anti-corruption body ${ }^{65}$ Indonesia established the Corruption Eradication Commission as measures to implement Article 6 of the UNCAC.

The international human rights instruments emphasized the State obligations on the need to establish universal health care and Indonesia has already taken progressive measures in establishing universal health care in 2014. The strategy to make an effective anti-fraud system is the subsequent step that has to be taken as a form of responsibility to protect universal health care. Protection of JKN fund from corruption is a part of the realization of the right to health for the people. In February 2017, the Social Insurance Administration Organization and the Corruption Eradication Commission have agreed to establish the task force to eliminate fraud in JKN.66 Therefore, in status quo, there are two task forces to combat fraud in JKN, the first is the internal task force from the Social Insurance Administration Organization and the second is the anti-fraud task force of the Social Insurance Administration Organization and the Corruption Eradication Commission. The relationship of tasks and duties of the newly formed anti-fraud task force has not yet been regulated further. Since there are many authorities that are involved then the law has to design the hierarchy of authority between the stakeholders to ensure the check and balances and also in a pragmatic way, enhance effectivity and efficiency of actions.

However, the lack of a specific law concerning an anti-fraud system makes the whole process of internalizing international law into national law become deficient. The current anti-fraud system is based on an independent set of laws from the legal instruments of ratification, a legal continuum on human rights, anti-corruption and universal health care. There are elements of the anti-fraud system in each of these laws because the unified and comprehensive anti-fraud law has not been formulated yet. Indonesia has regulated in the Law number 12 of 2011 concerning the hierarchy of legal instruments in Indonesia. The highest law is the Constitution and every law in Indonesia has to be coherence with the Constitution. The designated anti-fraud system has to be created by law and it has to be in a form of the highest national law below the Constitution in the hierarchy of laws in Indonesia. The law concerning anti-fraud system can be made as a new legal instrument or as an amendment of the existing anticorruption laws. ${ }^{67}$ With regard to good governance, the good governance principles need to embodied in with the focus on good governance, good corporate governance and good civil society governance. ${ }^{68}$

Article 25 of the Regulation of Social Security Agency number 1 of 2014 guarantees the right of JKN member to give a complaint to the health facilities and Social Security Agency and obtain information concerning health service. The Social Insurance Administration Organization Regulation also managed to put whistleblower provisions in Article 10. However, human development index in Indonesia is 0,689 in $2015 .{ }^{69}$ It is categorized as a medium human development which implies that Indonesia is still progressing in health and education. ${ }^{70}$ An effective whistleblowing activity

65 Neumayer, E. (2013). The Pattern of Aid Giving: The Impact of Good Governance on Development Assistance, London: Routledge, p. 8

66 The Social Insurance Administration Organization, https://bpjs-kesehatan.go.id/bpjs/index.php/post/read/ 2017/534/Bersama-Wujudkan-Program-JKN-KIS-Bebas-dari-Kecurangan, accessed 12 December 2017.

67 Ibid.

68 Osterhaus, A. (2010). Whistleblowing: An Effective Tool in the Fight Against Corruption, Berlin: Transparency International, p. 1-4.

69 Human Development Index, http://hdr.undp.org/en/countries/profiles/IDN, accessed 10 January 2018.

70 Ibid. 
demands a comprehensive understanding of human rights from the whistleblower. With the knowledge of human rights, people can demand and oversight the realization of human rights from the Government. Human rights education has to be improved to foster the initiative of the civil society to oversight the universal health care program since the legal guarantee for civil society participation has been regulated in Article 25 of the Regulation of Social Security Agency Number 1 of 2014. ${ }^{.1}$ Civil society has to become the guardian to watch the anti-fraud task forces operate by virtue that it will enhance the effectivity of the whole anti-fraud strategy and ensure better protection for JKN fund. The risk of fraud can be minimalized by the culture of check and balance from the citizen. Good governance, human rights and anti-corruption are mutually reinforcing and the combination of these three elements will strengthen the anti-fraud system in universal health insurance program.

\section{Conclusion}

Though fraud is often recognized as a victimless crime, it has a palpable correlation with the realization of human rights. Indonesia sets the example of a country with international human rights obligations to realize the right to health by means of establishing universal health care system. Indonesia also has the international legal obligations of UNCAC to establish measures to combat corruption. There is an intersection between the international human rights obligations and international anticorruption obligations. Good governance principles are consolidated in those obligations. Based on the research, there are considerable remarks in reference to the current anti-fraud system in universal health insurance. There is a necessity to further govern the legal vacuum in the areas such as the clarification of the tasks and duties of the anti-fraud task forces, stronger whistleblower protection, monitoring and control. Without a strong, comprehensive and clear legal basis concerning the anti-fraud system, there will be risks of ambiguous tasks and duties of the authoritative organs and it will hamper the progress of protecting the JKN fund from fraudulent activities. The legal foundation is incomprehensive and needs to be widened with more specific rules concerning anti-fraud and especially how it related to good governance principles. The good governance principles are vital to be applied as a key to integrating the realization of human rights and anti-corruption strategy. The anti-fraud system is not a panacea for the whole problem of corruption in the health sector, however, it acts as a milestone for better universal health insurance and good governance in Indonesia.

\section{References}

Books

Neumayer, E. (2013). The Pattern of Aid Giving: The Impact of Good Governance on Development Assistance, London: Routledge.

Office of the High Commissioner for Human Rights, (2007). Good Governance Practices for the Protection of Human Rights, Geneva: United Nations.

Office of the United Nations High Commissioner for Human Rights. (2013). The Human Rights Case Against Corruption, United Nations. http://www.ohchr.org/Documents/ Issues/Development/GoodGovernance/Corruption/HRCaseAgainstCorruption.pdf accessed 10 December 2017.

71 Osterhaus, A., supra note. 
OECD. (2008). Corruption: A Glossary of International Standards in Criminal Law, Paris: OECD.

Osterhaus, A. (2010). Whistleblowing: An Effective Tool in the Fight Against Corruption, Berlin: Transparency International.

Salter, M. \& Mason, J. (2007). Writing Law Dissertations Conduct of Legal Research, Edinburgh: Pearson Education Limited.

Transparency International. (2014). Protecting Climate Finance-An Anti-Corruption Assessment of the UN-REDD Programme, Berlin: Transparency International.

Journals

Brundtland, G. H. (1998). "Fifty Years of Synergy between Health and Rights". Health and Human Rights Journal, 3(2):21-25.

Butt, S. (2011). "Anti-corruption Reform in Indonesia: An Obituary?", Bulletin of Indonesian Economic Studies, 47(3):381-394.

Butt, S. (2009). "“Unlawfulness" and Corruption Under Indonesian Law”, Bulletin of Indonesian Economic Studies, 45(2):179-198.

Farmer, P. \& Gastineau Nicole, G. (2002). "Rethinking Health and Human Rights: Time for A Paradigm Shift", Journal of Law and Medical Ethics, 30(4):655-666.

Gathii, J. T. (2009). "Defining the Relationship between Human Rights and Corruption", University of Pennsylvania Journal of International Law, 31(1):125-202.

Hamilton-Hart, N. (2001). "Anti-corruption Strategies in Indonesia", Bulletin of Indonesian Economic Studies, 37(1):65-82.

Juwita, R. (2017). "Health Sector Corruption as the Archenemy of Universal Health Care in Indonesia", Mimbar Hukum, 29(1):162-175.

Lu, R. J. \& Hsiao, W. C. (2003). “Does Universal Health Insurance Make Health Care Unaffordable? Lessons from Taiwan", Health Affairs, 22(3):77-88.

Mboi, N. (2015) "Indonesia: On the Way to Universal Health Care", Health System Reform, 1(2):91-97.

McLeod, R. H. (2000). “Soeharto's Indonesia: A Better Class of Coruption”, Agenda: A Journal of Policy Analysis and Reform, 7(2): 99-112.

Setiyono, B. \& McLeod, R. H. (2010). "'Civil Society Organisations' Contribution to the Anti-corruption Movement in Indonesia", Bulletin of Indonesian Economic Studies, 46(3):347-370.

Sherlock, S. (2002). "Combating Corruption in Indonesia? The Ombudsman and the Assets Auditing Commission", Bulletin of Indonesian Economic Studies, 38(3): 367383.

Suryadarma, D. (2012). "How Corruption Diminishes the Effectiveness of Public Spending on Education in Indonesia", Bulletin of Indonesian Economic Studies, 48(1):85-100.

Tyler, E. T. (2013). "'Small Places Close to Home': Toward A Health and Human Rights Strategy for the US". Health and Human Rights Journal, 15(2):80-96. http://www.ncbi.nlm.nih.gov/pubmed/24421171

Türmen, T., Troedsson, H. \& Stahlhöfer, M. (2001). “A Human Rights Approach to Public Health: WHO Capacity Building in the Area of Children's Rights". Health and Human Rights Journal, 147-154.

Yamin, A. E. (2010). “Our Place in the World: Conceptualizing Obligations Beyond Borders in Human Rights-Based Approaches to Health". Health and Human Rights Journal, 12(1): 3-14. 


\section{Treaties}

Universal Declaration of Human Rights, art. 25, 1, 1948, U. N. G. A. RES 217 (III), U. N. DOC A/810, 71 .

European Social Charter, art. 11 and 13, Feb. 26, 1965, 529 U. N. T. S. 89.

International Convention on All Forms of Racial Discrimination, 1966, 660 U. N. T. S. 195.

International Covenant on Economic, Social and Cultural Rights, art. 12, 2, Dec. 16, 1966, 993 U. N. T.S. 3.

Convention on the Elimination of All Forms of Discrimination Against Women, Dec. 18, 1979, 1249 U. N. T. S. 13.

Convention on the Rights of the Child, Nov. 1989, 1577 U. N. T. S. 3.

African Convention on Human and People's Rights, art. 16, 1982, 21 I. L. M. 58.

Additional Protocol to the American Convention on Human Rights in the Area of Economic, Social and Cultural Rights (Protocol San Salvador), 1988, O. A. S. T. S. 69.

African Charter on the Rights and Welfare of the Child, art. 14, 1990, O. A. U. Doc. CAB/LEG/24.9/49.

Organization for Economic Cooperation and Development, Convention on Combating Bribery of Foreign Public Officials in International Business Transactions, Dec. 17, 1997, S. Treaty Doc. No. 105-43.

Organization of American States, Inter-American Convention Against Corruption, Mar. 29, 1996, S. Treaty Doc. No. 105-39, 35 I.L.M 724.

European Union, Convention on the Fights against Corruption involving Officials of the European Communities or Officials of Member States of the European Union, May. 26, 1997, Off. J. C195/1.

Council of Europe, Criminal Law Convention, Jan. 27, 1999, 2216 U. N. T. S. 225.

Council of Europe, Civil Law Convention on Corruption, Nov. 4, 1999, 2246 U. N. T. S. 4.

Council of Europe, Additional Protocol to the Criminal Law Convention on Corruption, May. 15, 2003, 2466 U. N. T. S. 168.

United Nations Convention Against Corruption, Oct. 31, 2003, 2349 U. N. T. S. 41.

Convention on the Rights of Persons with Disabilities, 2007, A/RES/61/106.

African Union, African Union Convention on Preventing and Combating Corruption, Jul. 11, 2003, 43 I. L. M. 5.

National Laws

Indonesia, the Law number 28 of 1999 concerning Clean Governance Free from Corruption, Collusion and Nepotism.

Indonesia, the Law Number 24 of 2001 concerning Social Insurance Administration Organization.

Indonesia, the Law Number 40 of 2004 concerning National Social Security System.

General Comments from the United Nations Human Rights Bodies

CESCR General Comment No. 14: The Right to the Highest Attainable Standard of Health (Art. 12), 2000 (2000).

Commission on Human Rights. (2004). Resolution 2000/64, The Role of the Good Governance in the Promotion of Human Rights. 
Reports

BPJS Kesehatan, (2015). Laporan Pengelolaan Program Tahun 2016 and Laporan Keuangan Pengelolaan Program Tahun 2016 (Audit), Jakarta: BPJS Kesehatan, http://bpjs-kesehatan.go.id/bpjs/index.php/arsip/detail/835.

Hidayat, B. et al. (2015) Financial Sustainibility of the National Health Insurance in Indonesia: A First Year Review Indonesian-German Social Protection Programme (SPP), https://goo.gl/o6dAWy, accessed 10 December 2017.

UNODC, Thematic Programme- Action Against Corruption, Economic Fraud \& IdentityRelated Crime (2012-2015), (2012). http://www.unodc.org/documents/corruption/ Thematic_Programme/Thematic_Programme_on_Corruption_-2012-2015_sept12.pdf.

Websites

Faizal, E. B. (2014). 8.5 million employees registered as BPJS members as of January: Ministry, the Jakarta Post, http://www.thejakartapost.com/news/2014/02/04/85million-employees-registered-bpjs-members-january-ministry.html, accessed 13 January 2018

Faizal, E. B. (2017) How Can We Save Our National Health Insurance Program from Deficit?, the Jakarta Post, https://www.pressreader.com/indonesia/the-jakartapost/20170411/281547995752075, accessed 13 January 2018.

Human Development Index, http://hdr.undp.org/en/countries/profiles/IDN, accessed 10 January 2018.

Jakarta Post, 23 February 2017, http://www.thejakartapost.com/news/2017/02/23/task-forceset-up-to-combat-jkn-fraud.html, accessed 13 January 2018

Jakarta Post, 24 February 2017, http://www.thejakartapost.com/news/2017/02/24/nationalscene-task-force-set-combat-jkn-fraud.html, accessed 13 January 2018.

Jong, H. N. (2015) Poor cost control will worsen JKN deficit: Study, the Jakarta Post, http://www.thejakartapost.com/news/2015/07/22/poor-cost-control-will-worsen-jkndeficit-study.html, accessed 13 January 2018.

OHCHR, http://www.ohchr.org/EN/NewsEvents/Pages/DisplayNews.aspx?NewsID=21476E LangID $=E$, accessed 11 January 2018.

Razavi, L. Indonesia's universal health scheme: one year on, what's the verdict?, the Guardian, https://www.theguardian.com/global-development-professionals-network/ 2015/may/15/indonesias-universal-healthcare-insurance-verdict, accessed 13 January 2018.

Tempo, (2017) BPJS Faces Major Deficit in 2017, https://en.tempo.co/read/news/2017/ 02/10/055845185/BPIS-Faces-Major-Deficit-in-2017, accessed 13 January 2018.

The Social Insurance Administration Organization, https://bpjs-kesehatan.go.id/bpjs/ index.php/post/read/2017/534/Bersama-Wujudkan-Program-IKN-KIS-Bebas-dariKecurangan, accessed 12 December 2017.

The Ministry of Health, Indonesia, http://www.depkes.go.id/article/view/17022400006/kpkgandeng-kemenkes-dan-bpjs-bentuk-satgas-pencegahan-dan-penanganan-fraud-sistem$j k n . h t m l$, accessed 13 January 2018

Transparency International, Corruption Perception Index: Indonesia, 2016, https://www.ti.or.id/index.php/publication/2017/01/25/corruption-perceptions-index$\underline{2016}$, accessed 13 January 2018.

The Social Insurance Administration Organization, https://bpjs-kesehatan.go.id/ bpjs/index.php/post/read/2017/534/Bersama-Wujudkan-Program-JKN-KIS-Bebas-dariKecurangan, accessed 12 December 2017. 
United Nations Treaty Series, https://goo.gl/onLUWn, accessed 13 January 2018.

United Nations Treaty Series, https://wwww.unodc.org/documents/treaties/UNCAC/COSP/ session4/V1186007e.pdf, accessed 12 December 2017.

WHO, Universal Health Coverage and Health Financing in Indonesia, http://www.searo.who.int/indonesia/topics/hs-uhc/en/, accessed 13 January 2018.

WHO, http://www.searo.who.int/indonesia/topics/hs-uhc/en/, accessed 8 December 2017.

WHO, http://www.who.int/mediacentre/factsheets/fs395/en/, accessed 9 January 2018. 